\title{
Comparison of Ni-Ti-Si Alloy Prepared by Various Powder Metallurgy Routes
}

Pavel Salvetr, Benoit Daney, Pavel Novák

University of Chemistry and Technology, Department of Metals and Corrosion Engineering, Technicka 5, 16628 Prague 6, Czech Republic, Email: salvetrp@vscht.cz, benoit.daney@etu.unilim.fr, panovak@vscht.cz

This work describes three ways of preparation of Ni-Ti-Si shape memory alloy by powder metallurgy methods. The self-propagating high-temperature synthesis, combination of self-propagating high-temperature synthesis, milling and spark plasma sintering and mechanical alloying with following spark plasma sintering were applied to $\mathrm{Ni}$-Ti-Si powder mixture. The differences in microstructure, phase composition, transformation temperatures and mechanical properties were observed and at the same time these properties were compared with other $\mathrm{Ni}$ - $\mathrm{Ti}$ and Ni-Ti-X alloys.

Keywords: Ni-Ti-X alloy, Powder metallurgy, Self-propagating high-temperature synthesis, Spark plasma sintering, Mechanical alloying

\section{Acknowledgement}

Financial support from specific university research (MSMT No 20-SVV/2016) and Czech Science Foundation, project No. 14-03044S.

\section{References}

[1] W.M. HUANG, Z. DING, C.C. WANG, J. WEI, Y. ZHAO, H. PURNAWALI (2010). Shape memory materials. Materials Today, Vol. 13, pp. 54-61.

[2] J. MOHD JANI, M. LEARY, A. SUBIC, M.A. GIBSON (2014). A review of shape memory alloy research, applications and opportunities. Materials \& Design, Vol. 56, pp. 1078-1113.

[3] T. DUERIG, A. PELTON, CH. TREPANIER (2011). Nitinol - PART I Mechanism and Behaviour, SMST e-Elastic newsletter, ASM International.

[4] K.S. SURESH, D.I. KIM, S.K. BHAUMIK, S. SUWAS (2014). Evolution and stability of phases in a high temperature shape memory alloy Ni49.4Ti38.6Hf12. Intermetallics, Vol. 44, pp. 18-25.

[5] R. SANTAMARTA, R. ARRÓYAVE, J. PONS, A. EVIRGEN, I. KARAMAN, H.E. KARACA, R.D. NOEBE (2013). TEM study of structural and microstructural characteristics of a precipitate phase in Ni-rich Ni-Ti-Hf and Ni-Ti-Zr shape memory alloys. Acta Materialia, Vol. 61, pp. 6191-6206.

[6] Y. KAIEDA (2003). Fabrication of composition-controlled TiNi shape memory wire using combustion synthesis process and the influence of Ni content on phase transformation behavior. Science and Technology of Advanced Materials, Vol. 4, pp. 239-246.

[7] K. OTSUKA, X. REN (2005). Physical metallurgy of Ti-Ni-based shape memory alloys. Progress in Materials Science, Vol. 50, pp. 511-678.

[8] J. FRENZEL, E.P. GEORGE, A. DLOUHY, C. SOMSEN, M.F.X. WAGNER, G. EGGELER (2010). Influence of $\mathrm{Ni}$ on martensitic phase transformations in NiTi shape memory alloys. Acta Materialia, Vol. 58, pp. 3444-3458.

[9] J. FRENZEL, Z. ZHANG, K. NEUKING, G. EGGELER (2004). High quality vacuum induction melting of small quantities of NiTi shape memory alloys in graphite crucibles. Journal of Alloys and Compounds, Vol. 385, pp. 214-223.

[10] A. FOROOZMEHR, A. KERMANPUR, F. ASHRAFIZADEH, Y. KABIRI (2011). Investigating microstructural evolution during homogenization of the equiatomic NiTi shape memory alloy produced by vacuum arc remelting. Materials Science and Engineering: A, Vol. 528, pp. 7952-7955.

[11] V. KUČERA, J. ČAPEK, A. MICHALCOVÁ, D. VOJTĚCH (2014). Preparation and characterization of niti shape memory alloy preparedby powder metallurgy. Manufacturing Technology, Vol. 14, pp. 342-347.

[12] P. NOVÁK, L. MEJZLÍKOVÁ, A. MICHALCOVÁ, J. ČAPEK, P. BERAN, D. VOJTĚCH (2013). Effect of SHS conditions on microstructure of NiTi shape memory alloy. Intermetallics, Vol. 42, pp. 85-91.

[13] P. NOVÁK, J. KŘÍŽ, A. MICHALCOVÁ, P. SALVETR (2015). Role of Reactive Sintering in Production of Technically Important Intermetallics. Manufacturing Technology, Vol. 15, pp. 74-77. 
[14] P. NOVÁK, H. MORAVEC, P. SALVETR, F. PRŮŠA, J. DRAHOKOUPIL, J. KOPEČEK, M. KARLÍK, T.F. KUBATÍK (2015). Preparation of nitinol by non-conventional powder metallurgy techniques. Materials Science and Technology, Vol. 31, pp. 1886-1893.

[15] M.T. ANDANI, N. SHAYESTEH MOGHADDAM, C. HABERLAND, D. DEAN, M.J. MILLER, M. ELAHINIA (2014). Metals for bone implants. Part 1. Powder metallurgy and implant rendering. Acta Biomaterialia, Vol. 10, pp. 4058-4070.

[16] M. BRAM, A. AHMAD-KHANLOU, A. HECKMANN, B. FUCHS, H.P. BUCHKREMER, D. STÖVER (2002). Powder metallurgical fabrication processes for NiTi shape memory alloy parts. Materials Science and Engineering: A, Vol. 337, pp. 254-263.

[17] M.H. ELAHINIA, M. HASHEMI, M. TABESH, S.B. BHADURI (2012). Manufacturing and processing of NiTi implants: A review. Progress in Materials Science, Vol. 57, pp. 911-946.

[18] C. SURYANARAYANA (2001). Mechanical alloying and milling. Progress in Materials Science, Vol. 46, pp. 1184.

[19] Z.A. MUNIR, U. ANSELMI-TAMBURINI, M. OHYANAGI (2006). The effect of electric field and pressure on the synthesis and consolidation of materials: A review of the spark plasma sintering method. Journal of Materials Science, Vol. 41, pp. 763-777.

[20] P. NOVÁK, T. VESELÝ, I. MAREK, P. DVOŘÁK, V. VOJTĚCH, P. SALVETR, M. KARLÍK, P. HAUŠILD, J. KOPEČEK (2016). Effect of Particle Size of Titanium and Nickel on the Synthesis of NiTi by TE-SHS. Metallurgical and Materials Transactions B, Vol. 47, pp. 932-938.

[21] M. WHITNEY, S.F. CORBIN, R.B. GORBET (2009). Investigation of the influence of Ni powder size on microstructural evolution and the thermal explosion combustion synthesis of NiTi. Intermetallics, Vol. 17, pp. 894-906.

[22] P. SALVETR, P. NOVÁK, H. MORAVEC (2015). Ni-Ti Alloys Produced by Powder Metallurgy. Manufacturing Technology, Vol. 15, pp. 689-694.

[23] P. SALVETR, T.F. KUBATÍK, P. NOVÁK. Preparation of Ni-Ti shape memory alloy by spark plasma sintering method. Manufacturing Technology, in press.

A. ŠKOLÁKOVÁ, P. NOVÁK, P. SALVETR. Influence of Elements with High Affinity to Oxygen on Microstructure and Phase Composition of Ni-Ti Alloy. Manufacturing Technology, in press. 